\section{As múltiplas notabilidades de Afonso \\ Arinos: biografias, memórias e a \\ condição de elite no Brasil do século XX}

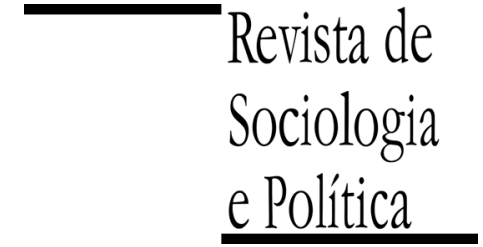

DOI 10.1590/1678-987315235403

\author{
Igor Gastal Grill
}

\title{
Resumo
}

No artigo são analisadas as bases sociais e os suportes institucionais que constituem as multinotabilidades de Afonso Arinos, protagonista de disputas políticas e intelectuais ao longo do século XX no Brasil. O foco recai, por um lado, nos amálgamas entre notoriedade social (genealógica, familiar, profissional e intelectual) e reputação política (atribuições, cargos, lideranças, atributos e feitos), por outro, nas tensões decorrentes das responsabilidades herdadas, da divisão do trabalho político familiar, da inscrição em domínios diversos, da compatibilidade de gramáticas divergentes, entre outras. A partir da produção biográfica e autobiográfica relativa ao personagem são exploradas: (i) as articulações entre a "vocação" para representar (nos mais variados sentidos que a expressão pode adquirir) e a "arte" de escrever; (ii) os usos sociais, ideológicos e políticos do trabalho coletivo de produção de créditos sobre uma personalidade política; (iii) a gestão da própria imagem e as teorizações nativas sobre a profissão política presentes nas memórias de um político. O tratamento dessas dimensões revela os contornos de um mosaico de competências legítimas para a consagração política e intelectual: habilidades, saberes e trunfos não necessariamente conciliáveis ou livres de processos traumáticos originários da justaposição ou redefinição de papeis, ocasionados, por sua vez, pela reconfiguração do espaço político e por exigências de readequação das estratégias de reprodução familiar. Do mesmo modo, mediante a análise de um conjunto de tomadas de posição do personagem e sobre ele vêm à tona distintos mecanismos edificadores da "multinotabilidade" do agente e de certos domínios de inserção, que aparecem como produtos e produtores da multiposicionalidade desfrutada por uma elite letrada e votada que comandou, simultaneamente, diferentes esferas de atuação política e cultural. Conjuga-se a isso, a possibilidade de compreender como o volume dos capitais possuídos e a combinação entre eles conferem a Afonso Arinos não somente a autoridade para produzir, manipular e impor definições sobre o exercício do métier do político e do "homem de letras", como também o potencial sem equivalentes acumulado para a gestão de identidades estratégicas.

PALAVRAS-CHAVE: elite política; intelectuais; memórias; biografias; profissão política.

Recebido em 31 de Outubro de 2013. Aprovado em 15 de Janeiro de 2014.

\section{Introdução ${ }^{1}$}

\begin{abstract}
${ }^{1}$ O presente trabalho contou com o auxílio da Fapema por intermédio de bolsa de estímulo à produtividade em pesquisa (BEPP) e de financiamento ao projeto "Produção Escrita e Carreiras Políticas no Brasil" (Edital - 001-2012 Universal). Registra-se também os agradecimentos aos pareceristas anônimos da Revista de Sociologia e Política.
\end{abstract}

2 Trata-se de uma reapropria-
66 omo englobar em escassas páginas cada uma das múltiplas faces desse poliedro humano?", indagou Pedro Nava, referindo-se a seu contemporâneo de "rodas intelectuais" e conterrâneo de Minas Gerais, Afonso Arinos de Melo Franco, em prefácio intitulado "Afonso", escrito para o livro-entrevista $O$ intelectual e o político: encontros com Afonso Arinos (Nava 1983, p. 27). O médico e escritor Pedro Nava referia-se aos múltiplos e concomitantes papeis exercidos, ao longo do século $\mathrm{XX}$, por esse personagem da vida política e cultural. Destacou, para o plano da produção literária, a acumulação de títulos como "poeta", "ensaísta", "crítico", "cronista", "historiador", "biógrafo", "memorialista", "tratadista de direito" e "teórico político", bem como, para o plano político, as posições de destaque assumidas por Arinos como "o revolucionário", "o oposicionista", "o secretário estadual", "o deputado federal", "o Senador", "o ministro", "o embaixador" etc.

Propõe-se aqui perquirir exatamente sobre as bases sociais e os suportes institucionais que constituem as multinotabilidades ${ }^{2}$ de um agente de embates e 
ção da conceituação original de Weber (1987) acerca da conversão de determinadas bases de reconhecimento social em posições de poder que marcou a inserção política dos "notáveis", agora ajustadas às exigências próprias aos processos de especialização e profissionalização do jogo político. Para uma discussão mais detalhada, ver a introdução do dossiê publicado na revista Politix (2004) e Grill e Reis (2015).

${ }^{3}$ Produto de uma sequência de investiduras mediante a qual ritos de instituição transformam a autoimagem de um agente e as representações dos demais sobre ele (Bourdieu 1996a), o reconhecimento desfrutado e reivindicado por personalidades públicas desvela-se com riqueza de detalhes no trabalho (sempre retrospectivo) de produção biográfica e autobiográfica sobre elas.
${ }^{4}$ A inspiração são os trabalhos de Collovald (1999, 1988) sobre Jacques Chirac.

${ }_{5}$ Neveu (2003) sugere que as autobiografias de políticos sejam abordadas por esse duplo ângulo. de eventos que marcaram o século XX no terreno da produção literária e da política do Brasil ("revoluções", partidos, parlamentos, governos etc.). Mais especificamente, serão abordados os amálgamas entre notoriedade social (genealógica, familiar, profissional e intelectual) e reputação política (atribuições, cargos, lideranças, atributos e feitos) ativados em estratégias discursivas, presentes em fontes biográficas e nas próprias memórias de Afonso Arinos $^{3}$, com vistas à atribuição/aquisição de estima social.

Os trabalhos que se inspiram no esquema analítico de Pierre Bourdieu (como o aqui empreendido) enfatizam a multidimensionalidade do espaço social (Bourdieu 1989). Por conseguinte, as posições sociais dos agentes são identificadas com base na diferenciação e distribuição de propriedades sociais em universos dotados de relativa autonomia e pautados por princípios de legitimação próprios, os chamados campos. Essa forma de conceber a topologia social exige, por sua vez, que sejam recenseadas as multiplicidades de posições ocupadas na estrutura social pelos membros das principais instâncias, lugares, meios de atuação das "elites", verificando a vinculação entre a multiposicionalidade desses indivíduos e a superfície social que os mesmos dispõem. Isto é, inventariar o volume e a estrutura dos capitais detidos com base tanto nas posições sucessivamente ocupadas ao longo do tempo como nas inscrições e investimentos simultaneamente efetuadas em diferentes domínios (Boltanski 1973).

Contudo, em configurações históricas como a brasileira a forte multidimensionalidade que condiciona as práticas e os reconhecimentos de porta-vozes situados em âmbitos políticos e culturais, assim como a necessidade de pensar amálgamas e conexões nas quais os registros de atuação política e intelectual são indiscerníveis, impõe alguns cuidados na utilização de conceitos e noções que não são transculturais e transferíveis de um contexto para o outro. A justaposição no espaço nacional entre lógicas e princípios que regem os universos da política e da intelectualidade em condições periféricas constitui uma fonte de obstáculos para a ativação do arsenal conceitual. Alia-se a isso a configuração do espaço transnacional fortemente hierarquizado entre centros e periferias, exigindo o acesso/reconhecimento junto aos polos exportadores de saberes, conhecimentos, tecnologias, expertises etc. para afirmação (Pécaut 1990; Coradini 2003; Coradini e Reis 2012; Reis 2013).

Logo, a discussão que segue explora três eixos de análise em consonância com outras investigações que vêm sendo realizadas no âmbito do Laboratório de Estudos sobre Elites Políticas e Culturais (LEEPOC) da Universidade Federal do Maranhão. O primeiro reside nas articulações possíveis, no caso brasileiro, entre a "vocação" para representar (nos mais variados sentidos que a expressão pode adquirir) e a "arte" de escrever (Grill \& Reis 2012; Reis \& Grill 2015). O segundo eixo trata dos usos sociais, ideológicos e políticos da produção biográfica decorrente do trabalho coletivo de produção de créditos e/ou de transformação identitária para os quais colaboram instituições e agentes mobilizando suas forças sociais e suas competências específicas, além de utilizá-las para a atualização de estratégias de afirmação pessoal e (re)posicionamentos em

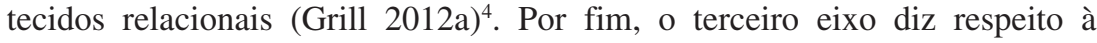
relevância heurística do exame de memórias de políticos. Essas fontes-objetos são instrumentos eficazes por um lado para apreender a gestão da própria imagem e, por outro, para captar teorizações nativas sobre a profissão política ${ }^{5}$ realizadas por agentes que se sentem autorizados e demandados a tornar públicas as suas "confissões" (Grill 2012b).

O caso de Afonso Arinos é adequado para perseguir pistas de estudo formuladas nos trabalhos anteriores. Por um lado, por ter adquirido um lugar proeminente no "panteão" de escritores brasileiros e no âmbito da política 
${ }^{6}$ Para citar apenas os parentes mais próximos, os avós paternos e maternos, o pai, Afrânio de Melo Franco, e o irmão, Vírgilio de Melo Franco, ocuparam cargos de destaque no cenário político nacional. Para mais detalhes sobre as origens sociais e trajetória de Afonso Arinos, ver Reis e Grill (2015).

${ }^{7}$ Nesse estudo mais amplo foram estudados deputados e Senadores, eleitos a partir de 1945 , que se caracterizam por uma atuação constante e equilibrada tanto no plano político (carreira profissionalizada) quanto literário (produção de livros). Foram relacionados perfis sociais e padrões de carreiras à produção de diferentes gêneros (generalista, especializado, literário, biografias histórias e confissões). A inspiração inicial foi o trabalho de Le Bart (1998). nacional acionando o duplo vínculo aos dois mundos e o reconhecimento desfrutado entre os pares desses domínios da vida social, o que permite tomá-lo como caso exemplar para apreensão de padrões recorrentes de vinculação entre política e cultura no Brasil do século XX. Por outro lado, seu perfil revela, em escala ampliada, pelo volume de recursos herdados e adquiridos, essas interdependências, trazendo ainda elementos ímpares (relacionados à configuração familiar) que conferem complexidade às justaposições em pauta.

Descendente de uma genealogia de políticos ${ }^{6}$, intelectuais e diplomatas, o parlamentar (deputado federal entre 1947 e 1958 e Senador entre 1959 e 1967 e 1987 e 1990, além de ministro das relações exteriores e secretário de estado por Minas Gerais), que conquistou relevo no plano político-partidário, sobressai-se - no conjunto de 299 casos analisados anteriormente por intermédio de uma sociografia de agentes situados em posições análogas (Grill \& Reis 2012) - pela produção constante, volumosa e equilibrada de obras que cobrem os mais variados gêneros ${ }^{7}$. Autor de várias dezenas de livros, chegou aos lugares mais consagrados da vida intelectual do país, como a Academia Brasileira de Letras (ABL), o Instituto Histórico e Geográfico Brasileiro (IHGB), o Conselho Federal de Cultura (CFC), entre outros.

Ademais, Arinos é alvo de um trabalho coletivo de eternização por parte de diversas instâncias de consagração, como o Centro de Pesquisa e Documentação da Fundação Getúlio Vargas e a Academia Brasileira de Letras, além de uma infinidade de comentaristas (escritores, juristas, políticos e familiares) e comentários laudatórios. Não raro, tal produção reforça seu reconhecimento como "memorialista" (autor de cinco volumes de memórias) e, não por acaso, esse foi um dos trunfos que o qualificou a controlar a transmissão da própria imagem, intervindo, assim, sobre as demais narrativas biográficas produzidas sobre ele.

Uma leitura apressada do material utilizado poderia, então, induzir a uma naturalização da sua condição de elite e a projetar nele um destino inelutável. O exame laborioso das narrativas biográficas e autobiográficas pode, no entanto, desvelar um personagem permeado por conflitos e ambivalências, derivados de pertencimentos simultâneos (dinâmica sincrônica) e diversificados de acordo com o trajeto pessoal e do grupo familiar (dinâmica diacrônica).

Com efeito, visando constituir um quadro de análise, alguns expedientes de investigação foram postos em prática. Em uma direção, por intermédio do exame das biografias, foram detectados os recursos sociais que alicerçam as múltiplas notabilidades do biografado, sem descuidar, contudo, de uma reflexão sobre o lugar ocupado pelas instâncias e agentes responsáveis por essas publicações. Desse modo, almejou-se compreender como "a representação do homem político resulta do encontro que se opera entre esses princípios de construção e as propriedades específicas que o caracterizam" (Collovald 1988, p. 29). Em outra direção complementar, mediante o estudo do corpus discursivo constituído pelos cinco volumes das memórias publicadas à luz do seu trajeto e de suas características sociais, interroga-se sobre $(i)$ as lógicas que presidem o tipo de relato produzido; (ii) as modalidades de estruturas narrativas; (iii) as formas de qualificação das obras efetuadas pelo próprio autor, por prefaciadores, editores etc.; (iv) as estratégias de seleção e hierarquização de eventos, personagens, etapas da vida, atributos e $(v)$ trunfos pessoais/familiares e os esforços de teorização do próprio jogo político ${ }^{8}$.

\section{As biografias: espelhos das memórias?}

${ }^{8}$ Os procedimentos de análise foram inspirados nos trabalhos
As fontes biográficas existentes sobre Afonso Arinos acompanham a diversidade de investimentos realizados pelo personagem ao longo da sua vida. 
de Le Bart (1998) e Neveu (2003).

\section{II.1. Afonso Arinos no "panteão" da elite política nacional: o verbete do DHBB}

${ }^{9}$ Foi utilizada a segunda edição impressa do DHBB, de 2001. Tal edição complementa as informações que não constavam na primeira (1984) e contém elementos gráficos não disponíveis na edição online veiculada desde 2010 .

${ }^{10}$ Trata-se do livro de Afonso Arinos intitulado Um estadista da República, publicado pela José Olympio Editora (Arinos 1955).

11 É importante mencionar que um dos organizadores do DHBB escreveu uma tese de doutoramento sobre Afonso Arinos, depois transformada quisa ${ }^{11}$.
Pode-se recorrer àquelas que privilegiam a atuação pública e institucional, como o esmerado e extenso (em termos de números de páginas) verbete sobre o percurso do "vulto" da política nacional, publicado no Dicionário Histórico e Biográfico Brasileiro, do Centro de Pesquisa e Documentação (CPDOC) da Fundação Getúlio Vargas (Abreu 2001). Traços biográficos podem ser reunidos ainda em homenagens presentes em livros escritos por pares da universidade e do mundo jurídico (Bonavides 1976; Venâncio Filho 1981); em artigos de jornais quando do seu falecimento; em prefácios aos seus próprios livros (alguns inclusive em forma de poemas "louvações" como o do seu contemporâneo de rodas intelectuais em Minas Gerais, Carlos Drumond de Andrade, ou dos escritores Alphonsus de Guimarães Filho e Odilo Costa, Filho, que abrem o quarto livro de memórias de Afonso Arinos); em discursos de sessões solenes da Academia Brasileira de Letras; ou em biografias publicadas a partir da cadeira ocupada na $\mathrm{ABL}$, em especial aquela redigida pelo filho que leva o seu mesmo nome, Afonso Arinos (Arinos Filho 2009).

Optou-se aqui por tomar, como casos ilustrativos, os relatos biográficos apresentados no DHBB do CPDOC-FGV (Abreu 2001) e no livro editado pela ABL redigido pelo seu filho, que atualmente é membro efetivo dessa instituição de consagração literária. Essa escolha se justifica por duas razões. Por um lado, porque esses textos incorporam, como fontes, as demais produções (fazendo, inclusive, referências e citações literais). Por outro, por possibilitarem compatibilizar dois registros aparentemente distantes. O primeiro centrado na dimensão pública (atuação em cargos partidários, responsabilidades governamentais, atuação em movimentos políticos) e pautado por uma iniciativa institucional. E o outro originado da esfera privada (familiar) e afiançado por uma instância de consagração literária. Um impessoal, o outro, pessoal e atávico (embebido em laços afetivos e em códigos originários do parentesco, da linhagem, da genealogia, enfim, das bases de constituição de "heranças"). Além disso, trata-se de dois relatos que realçam, em um caso, prioritariamente a notoriedade política e, no outro, a reputação intelectual, ao mesmo tempo demonstrando, de diferentes maneiras, a indissociabilidade das múltiplas dimensões de notabilização.

O verbete do Dicionário Histórico e Biográfico (DHBB) da Fundação Getúlio Vargas (FGV) dedica nove páginas ao trajeto de Afonso Arinos. Além do amplo espaço investido na caracterização do personagem, outro indicador da deferência devotada é a apresentação de uma foto do ex-deputado federal e ex-Senador. No que pese a publicação ser destinada exclusivamente à exibição das "figuras" da elite política posterior a 1930, os casos de protagonistas da vida política cuja biografia é ilustrada com foto(s) constituem raridades? ${ }^{9}$.

As fontes citadas e consultadas também denotam a excepcionalidade conferida ao biografado. Desde livros de cientistas políticos e historiadores até uma extensa gama de reportagens de jornais e revistas de circulação nacional como Veja e Jornal do Brasil, passando pela biografia histórica que Arinos produziu sobre o pai, situando-o no universo familiar ${ }^{10}$, e por suas próprias memórias. Portanto, o verbete traz um rol de referências das quais os dados procedem, sinalizando, assim, a importância adquirida pelo político na história republicana, a riqueza da sua produção escrita para a construção de uma "imagem", as ressonâncias dos seus textos em outras modalidades de fabricações de biografias e o destaque dado a ele no dicionário em termos de investimento em pes-

Em outros termos, percebe-se o movimento de interdependência e de incremento da notabilidade, ocasionados pelo encontro de um agente capaz de agir sobre a gestão da própria imagem (tornando-se ele mesmo uma fonte constante 
em livro. Ver LattmanWeltman (2005).

${ }^{12}$ Para uma discussão sobre a relevância de reconstituições de trajetos de agentes com a dupla inserção no terreno eleitoral (votados) e na produção de textos (letrados), ver Reis e Grill (2008).

${ }^{13}$ Uma análise detalhada foi realizada no texto que trata das "dinâmicas políticas, produção escrita e reputações pessoais" a partir do estudo de trajetória. Ver Reis e Grill (2015).

${ }^{14}$ Ver Miceli (1979), Pécaut (1990), Garcia Jr. (1993) e Coradini (2003). Sobre a proliferação, a diversidade e diferenciações entre as "coleções" denominadas "brasilianas", existentes no período em distintas editoras, ver Sorá (2010) e Pontes (1988).

15 Sobre a importância das "rodas", das "casas" e dos "panteões" na consagração de intelectuais brasileiros, ver, respectivamente, Sorá (2010) e Silva (2008), Coradini (2003) e Sorá (2010), e Coradini (1998), Almeida (2008), Quintella (1984) e Maia (2010).

${ }^{16}$ Afonso Arinos foi membro de instituições como: a Academia Brasileira de Letras, a Academia Mineira de Letras, o Instituto Histórico e

Geográfico Brasileiro, a Academia Nacional de História, a Academia Nacional de Educação, a Academia de Ciências Jurídicas, Conselho Federal de Cultura, entre outros. de material biográfico e histórico), via produção escrita, com o crescimento exponencial de registros históricos do seu percurso.

$\mathrm{O}$ verbete, por sua vez, divide-se em 12 partes. As mesmas abarcam diferentes momentos do trajeto de Afonso Arinos, interligando suas atuações nos âmbitos político-partidários, literários, jornalísticos e universitários. Cabe grifar o entrecruzamento dos seus movimentos com outros destinos de familiares (ascendentes, da mesma geração ou descendentes).

A partir desse material, pode-se observar, especialmente, uma narrativa que associa diferentes atributos que conferem ao personagem, simultaneamente, excepcionalidade e exemplaridade. Quer dizer, a caracterização da sua participação em vários eventos históricos (ricamente descritos) vem acompanhada da apresentação de competências, habilidades e saberes raros e imprescindíveis para aquelas situações. Da mesma forma, a gama de linguagens específicas às esferas de poder (faccionais, partidárias, parlamentares, governamentais, diplomáticas etc.) que teria dominado informa bastante sobre os múltiplos e cambiantes papeis prescritos para o exercício da profissão de político ao longo do século XX. Da mesma forma, a leitura do verbete possibilita acompanhar uma série de transformações e reconfigurações no universo de questões que mobilizaram a "elite" de letrados e votados ${ }^{12}$ no Brasil durante o século $\mathrm{XX}^{13}$.

Afonso Arinos fez parte de uma geração que assumiu a atribuição de construção da nação e das instituições entre as décadas de 1920 e 1940, por meio do trabalho intelectual-literário facilitado pela expansão do mercado editorial, principalmente surgimento de coleções voltadas para interpretar a nação ${ }^{14}$.

Atuou com protagonismos nas batalhas entre partidos, no interior de agremiações, em comissões e no plenário do parlamento, em ministérios de governos (presidencialistas e parlamentaristas) e em fóruns intergovernamentais do período denominado de democracia populista (1945-1964). Utilizando-se de canais institucionais que se delineavam paulatinamente e de forma precária, assim como dos espaços midiáticos (notadamente o jornalismo), posicionou-se sobre temas como regimes de governo, reformas políticas, legislação eleitoral, soberania e autodeterminação, entre outros.

Combinou o reconhecimento como intelectual - garantido por intermédio do pertencimento às "rodas intelectuais", da proximidade com as "casas dos editores" e da inscrição em "panteões"15 de letrados ${ }^{16}$ - com a intervenção política. Isso ocorreu tanto em períodos denominados "democráticos" (19451964; 1980-1990) como em regimes ditos “autoritários” (1937-1945 e 19641979).

Na fase final da carreira, no bojo da chamada redemocratização, agregou às certificações conquistadas via o acúmulo de títulos escolares, o exercício do magistério superior e a produção de livros e de artigos, outros conhecimentos e inserções como as técnicas relacionadas à produção de pesquisas de opinião e a atuação em fundações de estudos localizadas em partidos políticos e em conselhos na esfera pública. Com efeito, revestiu-se da nova linguagem do poder, afiançadas por uma imagem de credibilidade científica e pela adesão à ideologia democrática, cujos modelos são, geralmente, importados de instituições norteamericanas $^{17}$.

Na Tabela 1, são sistematizadas as principais ênfases identificadas no verbete do DHBB da FGV acerca das atribuições, trunfos e realizações no trajeto político de Afonso Arinos. 


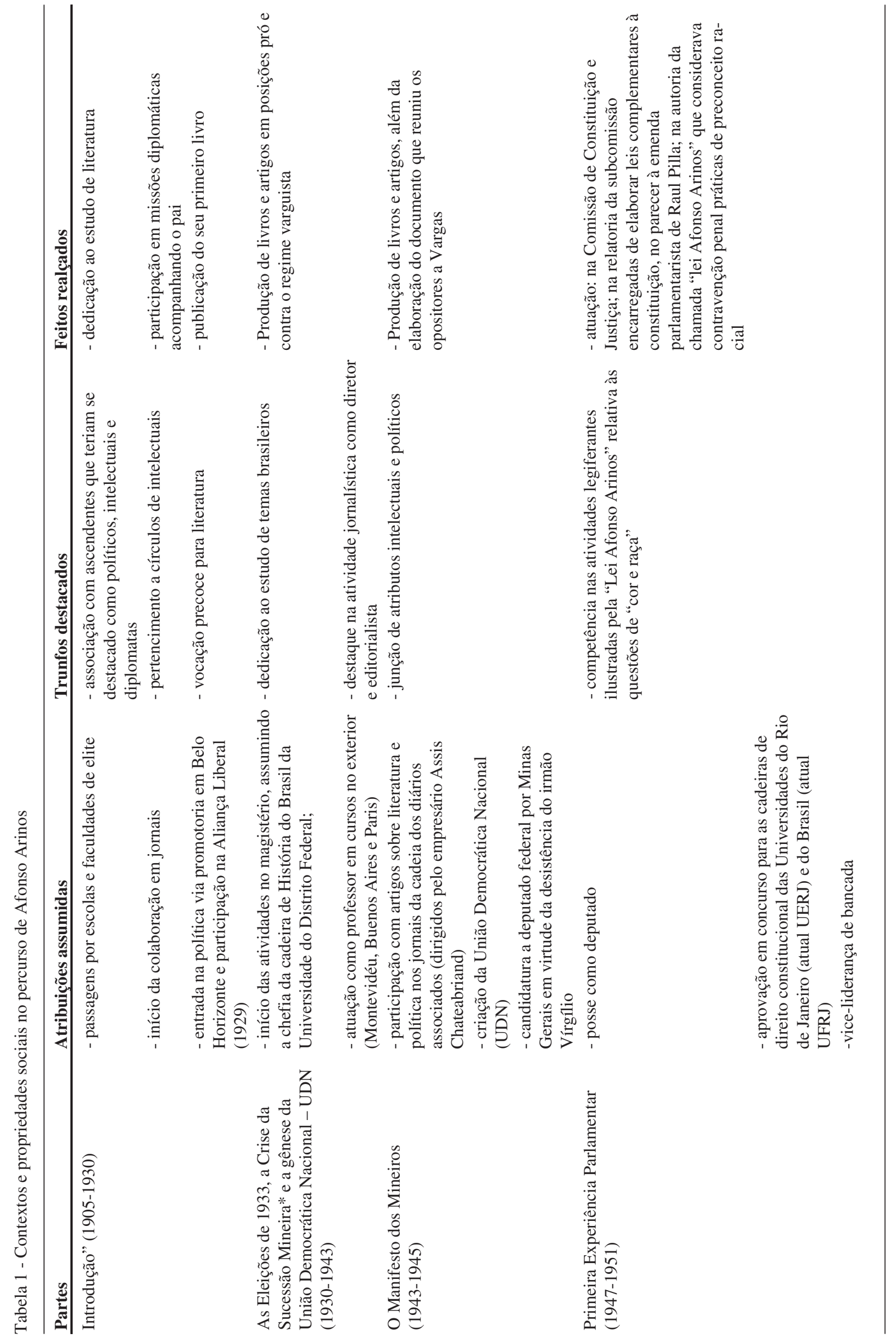




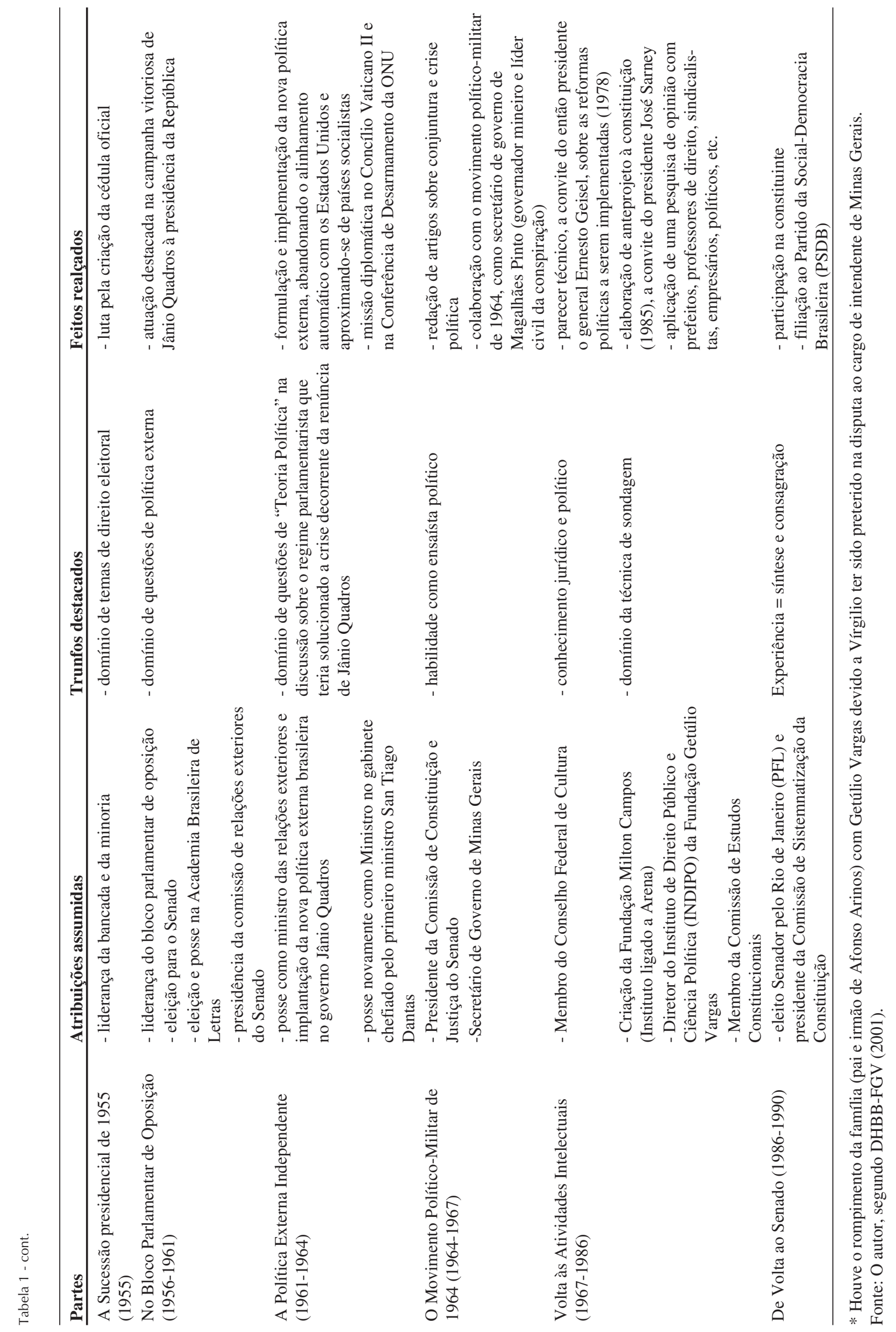




\section{II.2. Biografia, aferição de excelência social e inscrição genealógica: Afonso Arinos por Afonso Arinos Filho}

17 A reflexão sobre paralelismos, trocas e influências da relação norte-sul encontram-se em Dezalay e Garth (1998) e Guilhot (2001), entre outros.

${ }^{18} \mathrm{Na}$ família, além de Afonso Arinos, pai, quatro tios de Afonso Arinos Filho, o avô e dois bisavôs cursaram Direito, para citar apenas alguns e do lado paterno da família (Arinos 1961, p. 78).

${ }^{19} \mathrm{O}$ outro filho de Afonso Arinos, Francisco de Melo Franco, foi secretário de estado no Rio de Janeiro e candidato a vice-governador em 1982.

${ }^{20}$ Muitos dos personagens aos quais Afonso Arinos tem sido associado foram objetos de textos de celebração por ele escritos, edificando modelos de "estadistas" aos quais buscou também se aproximar.
Coube ao filho de Afonso Arinos, Afonso Arinos Filho, escrever uma pequena biografia sobre o pai em coleção patrocinada pela Academia Brasileira de Letras para celebrar seus membros "ilustres". Tal incumbência foi oportunizada pelo pertencimento do primeiro ao quadro de membros efetivos da Academia Brasileira de Letras (ABL), além, é claro, da ligação familiar. Contudo, a presença nesta instituição de notáveis letrados não é a única marca de continuidade entre pai e filho. Diplomata de carreira (com formação no Instituto Rio Branco), Afonso Arinos Filho também se formou em Direito ${ }^{18}$ pela Faculdade da Universidade do Brasil, em 1953, e ocupou cargos eletivos, sendo constituinte estadual, eleito pela UDN, e deputado federal na primeira metade dos anos $1960^{19}$. Ostenta ainda, em seu currículo, o título de sócio titular do Instituto Histórico e Geográfico Brasileiro (IHGB), sem deixar de chamar a atenção para o exercício das atividades de escritor e de professor universitário. Coordenou a campanha vitoriosa de Afonso Arinos (pai) ao Senado. Todavia, a última investida em pleitos eleitorais de Afonso Arinos Filho foi fracassada, não se elegendo deputado federal, em 1994. Dedicou-se desde então à atividade literária, a emissão de comentários sobre política internacional em rede de TV e ao magistério (Abreu 2001).

Apoiado nesse conjunto de créditos, Arinos Filho publicou, em 2009, uma síntese biográfica sobre o pai na série denominada "Essencial". Como consta na contracapa do volume, a coleção: "se propõe oferecer informações básicas sobre cada um dos ocupantes das 40 cadeiras da Academia Brasileira de Letras ao longo da História, bem como sobre os patronos da instituição". No texto em questão, além da inscrição da personalidade entre "aqueles que tiveram seus nomes para sempre vinculados a esta casa [ABL]", observa-se a associação do mesmo ao grupo familiar e do filho à genealogia por intermédio do pai.

O pequeno livro de 62 páginas traz uma introdução em que são acionados depoimentos de pares que teriam "testemunhado" as "múltiplas faces" de Afonso Arinos: Pedro Nava, José Sarney, Sérgio Buarque de Holanda, Heráclio Salles, Josué Montello. Dois elementos são grifados pelo filho nos depoimentos: a atividade política e os múltiplos gêneros de escrita aos quais se dedicou seu pai. A partir deles, uma sequência de vinculações pessoais efetuadas pelos acadêmicos acima listados é ressaltada, mormente entre Afonso Arinos e Joaquim Nabuco, mas também com Antonio Candido, José Bonifácio e Rui Barbosa ${ }^{20}$.

As simetrias estabelecidas contribuem à consagração daquele que é elevado à condição de "uma das figuras mais impressionantes de homem, intelectual e estadista" (Nava apud Arinos Filho 2009, p. 6), caracterizado por atributos como o "gosto das ideias políticas" (Sarney apud Arinos Filho 2009, p. 7), "a grandeza do sábio, pilar da nacionalidade" (idem, p. 8), entre outras passagens de exaltação. A essas qualidades atribuídas por notáveis da política e da intelectualidade brasileira que faziam parte do círculo de relações pessoais e institucionais do homenageado, soma-se o "autorretrato" do próprio personagem pinçado pelo filho para compor a moldura que comportaria a biografia. O "autorretrato", escrito por Afonso Arinos quando completara 70 anos, faz alusão às "Casas-grandes" de Belo Horizonte e do Rio de Janeiro, seus frequentadores vestidos de "fraques"; às instituições de ensino frequentadas no Brasil e no exterior; à dedicação à "palavra escrita e falada", expressa em "quase meia centena de livros; milhares de aulas [...]; à oratória parlamentar e popular [...]" (idem, p. 12) e assim por diante. Traços reforçados em poesia oferecida por um dos seus companheiros de geração de maior destaque, Carlos Drummond de Andrade, reproduzida neste livro. 
A biografia propriamente dita aparece logo em seguida com uma descrição das principais obras publicadas, realizada paralela e simultaneamente aos registros de atribuições profissionais e políticas assumidas, ganhando relevo as origens familiares, a atuação jornalística e sua imbricação com a política, a carreira docente e o trajeto de cargos públicos ocupados. Entremeadas a isso, algumas aptidões são sublinhadas, como para a literatura e a política, e as preocupações que seriam seus "legados" são engrandecidas, como aquelas em torno da "democracia", do "parlamentarismo", da "luta contra a discriminação racial", da busca pela "paz", da "soberania nacional" e da "autodeterminação dos povos". Esses itens serviram de parâmetro para a organização de uma ontologia que cobre a segunda metade da obra e que reproduz extratos de publicações, especialmente das memórias redigidas por Afonso Arinos. É obedecida a linearidade do relato biográfico, ao mesmo tempo em que se efetuam triagens que ligam pai e filho, mediante trunfos como inscrição genealógica, competência jurídica, diplomática e parlamentar.

A síntese operada pode ser visualizada na Tabela 2.

Tabela 2 - Síntese da Ontologia de Afonso Arinos por Afonso Arinos Filho

\begin{tabular}{|c|c|c|c|}
\hline Título & Obra & Contexto descrito & $\begin{array}{l}\text { Traços biográficos valori- } \\
\text { zados }\end{array}$ \\
\hline Berço & $\begin{array}{l}\text { A Alma do Tempo } \\
\text { (Memórias) }\end{array}$ & Casa em Belo Horizonte & $\begin{array}{l}\text { "Família senhoril", "altivez", } \\
\text { "tradição intelectual" }\end{array}$ \\
\hline Drama da Gripe Espanhola & $\begin{array}{l}\text { Um estadista da República: } \\
\text { Afrânio de Mello Franco e } \\
\text { seu tempo }\end{array}$ & Morte do irmão e da mãe & $\begin{array}{l}\text { Indistinção da esfera privada } \\
\text { e das atribuições públicas no } \\
\text { grupo familiar }\end{array}$ \\
\hline Um Baile em Petrópolis & $\begin{array}{l}\text { A Alma do Tempo } \\
\text { (Memórias) }\end{array}$ & $\begin{array}{l}\text { Festa em "Majestosa Resi- } \\
\text { dência" em que conheceu a } \\
\text { esposa }\end{array}$ & $\begin{array}{l}\text { Localização social da família } \\
\text { da esposa }\end{array}$ \\
\hline A Lei Afonso Arinos & $\begin{array}{l}\text { Discurso na instalação do } 2^{\circ} \\
\text { Congresso Brasileiro do Ne- } \\
\text { gro, em } 26 \text { de agosto de } 1950\end{array}$ & $\begin{array}{l}\text { Discriminação racial no } \\
\text { Brasil }\end{array}$ & $\begin{array}{l}\text { Importância da atividade } \\
\text { legiferante }\end{array}$ \\
\hline Saudade & A Escalada (Memórias) & $\begin{array}{l}\text { Morte do neto mais velho, } \\
\text { Virgílio, filho de Afonso } \\
\text { Arinos Filho. }\end{array}$ & $\begin{array}{l}\text { Reconstituição da linha- } \\
\text { gem, situando o biografado e } \\
\text { aquele que produz a biografia } \\
\text { via o descendente em comum }\end{array}$ \\
\hline Parlamentar & Planalto (Memórias) & $\begin{array}{l}\text { Saída da cena política durante } \\
\text { regime militar }\end{array}$ & Pertencimento geracional \\
\hline Política Externa & Evolução da Crise Brasileira & $\begin{array}{l}\text { Guerra Nuclear e o Brasil na } \\
\text { política mundial }\end{array}$ & Importância da Diplomacia \\
\hline Desarmamento & A Escalada (Memórias) & Diplomacia e busca da "paz" & Importância da Diplomacia \\
\hline Vida & $\begin{array}{l}\text { Alto-Mar Maralto } \\
\text { (Memórias) }\end{array}$ & Balanço de Vida & $\begin{array}{l}\text { Desprendimento material e } \\
\text { gostos legítimos }\end{array}$ \\
\hline Setenta Anos & $\begin{array}{l}\text { Alto-Mar Maralto } \\
\text { (Memórias) }\end{array}$ & Balanço de Vida & $\begin{array}{l}\text { "Dedicação à cultura, à tole- } \\
\text { rância e à liberdade" }\end{array}$ \\
\hline Morte & $\begin{array}{l}36^{\circ} \text { Encontro de Líderes e } \\
\text { Pessoas com Poder Decisório } \\
\text { nu Sumaré }\end{array}$ & $\begin{array}{l}\text { Digressão sobre o significado } \\
\text { da Morte }\end{array}$ & $\begin{array}{l}\text { Capacidade de distanciamen- } \\
\text { to e análise }\end{array}$ \\
\hline
\end{tabular}

Fonte: O autor, segundo Arinos Filho (2009). 


\section{Entre memórias e diários: passado-presente; política-literatura}

Depois de constatar a centralidade das memórias de Afonso Arinos na gestão das identidades estratégicas (Collovald 1988) e a forma como elas reverberam em outras produções biográficas, cumpre, nesta seção, deslindar, por meio do exame dos cinco volumes, uma série de aspectos mais gerais relacionados à imbricação entre formas de pensar a política e a cultura, em distintas configurações históricas, que emerge na leitura dos livros. Lembrando que as memórias são lugares privilegiados de observação tanto das estratégias simbólicas de apresentação de si, dos seus atributos, competências e trunfos, como da definição da profissão política, dos seus condicionantes, dos recursos mobilizáveis, dos movimentos exigidos/permitidos, e da incorporação de um conjunto de regras, sentidos e domínios práticos para atuar no espaço político especializado (Neveu 2003).

A abordagem adotada no trabalho de interpretação do corpus discursivo segue duas trilhas complementares. A primeira centra o olhar nas estratégias de auto-apresentação desse personagem da vida política brasileira, considerando-o como "ideólogo da sua própria vida" (Bourdieu 1996b, p. 75) e produtor de uma "apresentação oficial de si" (idem, p. 80). A segunda encontra nesses textos "uma expressão estimulante da relação vivida com o métier político, a intuição freqüentemente penetrante das suas lógicas" (Neveu 2003, p. 104).

\section{III.1. Afonso Arinos e a "elite política mineira"}

Inicialmente, cabe evidenciar particularidades que dizem respeito ao padrão de formação da "elite política mineira" e às propriedades sociais do personagem-autor que auxiliam na interpretação das obras. Logo, o procedimento de análise adotado aqui consiste em relacionar as narrativas vis-à-vis os condicionantes regionais, sociais e institucionais em pauta.

Alguns aspectos definidores do tipo de registro que Afonso Arinos imprime às suas memórias e a modalidade de escrita que ele ativa estão intimamente ligados às vinculações entre cultura e política próprias ao estado de Minas Gerais. Arruda (1999) demonstrou que os "memorialistas" contribuíram decisivamente para fundar a figura abstrata dos mineiros. Isto é, para a construção de uma "subcultura regional" (o "mineirismo") e para o endosso de práticas sociais e visões acerca da "realidade" do estado (a chamada "mineirice"). Desse modo, os relatos produzidos nesse tipo de escrita constituem-se em vetores de um "pensamento mítico" e de sua permanência. Adiciona-se a isso a produção cultural e a participação política, principalmente no plano nacional, como instrumentos de elaboração ideológica das especificidades regionais. Isso porque, por meio de "confissões escritas" e "discursos", reproduzem o "imaginário tecido sobre Minas" (idem, pp. 198-199).

A chamada "mineirice", como lembra Canêdo (1997) na esteira do trabalho de Arruda (idem), remete igualmente a uma forma de exercício das atribuições políticas que se pretende singular, revestindo-se de atributos como "astúcia", "habilidade de negociar, conciliar, acomodar". Dessa maneira, há a construção, o uso e a difusão de uma representação do "político mineiro" pelos próprios agentes nas suas narrativas. Naturalizando, por conseguinte, competências conquistadas em grupos familiares e em escolas de elites, e internalizando categorias de percepção, pensamento e de ação ao relacioná-las a um padrão regional singular de atuação política (Canêdo 1997, pp. 33-34). Dito de outro modo, habilidades e trunfos acumulados sob condicionantes específicos que marcam a reprodução de grupos familiares na política naquele cenário acabam se constituindo em qualidades tidas como "inatas" aos "mineiros", prescrevendo ainda condutas regionais modelares a partir de casos excepcionais ${ }^{21}$. 
"famílias de políticos", seus atributos e trunfos que conferem simultaneamente excepcionalidade e exemplaridade, e investimentos de singularização de contextos políticos regionais (naturalização de formas de atuação política), também foram abordadas na análise de "herdeiros" da "política gaúcha" e da "política maranhense", ver Grill (2008).

${ }^{22}$ Lattman-Weltman (2005, p 37) ressaltou como Afonso Arinos, ao idealizar e prescrever certas características do homem público, conseguiu "o resgate de uma época e de uma herança, a construção de uma linhagem, a valorização de uma tradição e, por fim, mas não menos importante, a definição de uma identidade tanto individual quanto coletiva".
A produção memorialística de Afonso Arinos acompanha algumas das diversas marcas que são comuns aos "memorialistas mineiros", apontadas por Arruda (1999). Tais como as referências mobilizadas no sentido de situar as narrativas na trama do imaginário de Minas, recriando-o e revitalizando-o, principalmente por intermédio de uma leitura saudosista do passado que, inevitavelmente, aparece acompanhada do descontentamento com o presente (idem, p. 200).

Conjuga-se a isso a explícita primazia de laços atávicos que encastram o agente em sua origem geográfica e a recuperação de raízes distintas e distintivas, sem excluir, no entanto, uma tendência universalizante. Quer dizer, as "memórias" produzidas se encontram ligadas nostalgicamente ao passado. Aparecem repletas, contudo, de caracterizações de "perfis universais", mesclando personagens descritos e modelos de condutas a serem valorizados e transmitidos ${ }^{22}$.

A articulação entre as particularidades do estado de Minas Gerais com vivências de desenraizamento social (por conta, por exemplo, dos afastamentos constantes em virtude de carreiras e atribuições políticas exercidas em centros políticos), traduz-se em "memórias" carregadas de "saudosismos" e "melancolias" que inflacionam a importância da "família" e das fases biográficas a ela relacionadas, como a "infância" e a "juventude". Enfim, uma intersecção entre o tempo presente e o tempo passado, por meio de relatos que interpõem experiências idiossincráticas e submissão a valores universais que prescrevem comportamento e códigos legítimos, proclamados e vividos como raros e próprios aos mineiros.

Nessa linha, Afonso Arinos descreve o grupo familiar alternando aqueles que seriam os componentes de uma "família mineira" modelar com a exaltação de elementos que singularizariam os protagonistas da sua linhagem.

As passagens abaixo são ilustrativas da localização feita por Afonso Arinos da "tradição política mineira" e de sua família. Ao mesmo tempo em que é possível detectar os investimentos efetuados para a inscrição no "legado" da "mineirice", pode-se entrever atributos valorizados e valorizadores de uma tradição intelectual considerada ímpar e rara mesmo entre a "elite mineira". Do mesmo modo, vem à tona a ambivalência decorrente da posição política de destaque alcançada pelos membros da família no cenário regional e nacional, com a existência de casos de líderes supostamente preteridos, traídos, não reconhecidos, mas que são exemplares para demarcar a "altivez" e a "coerência” no plano ideológico, programático etc. da família.

"“ autenticamente, uma família senhoril; de senhores mineiros, bem entendido, modestos, sem luxos nem riquezas, mas senhores. Isto é, gente simples mas altiva, incapaz de sofrer qualquer humilhação para subir na vida. $\mathrm{O}$ que os diferenciava, talvez, de outros grupos familiares no mesmo gênero, existentes no Estado, era a ininterrupta tradição intelectual que fazia da literatura na nossa casa, uma coisa comum, uma conversa de todo dia. A literatura nos acompanhava desde a colônia" (Arinos 1961, p. 22).

"Dos mineiros é que eu, deputado novato, me achava ao mesmo tempo mais próximo e mais distante. Mais próximo pelas relações pessoais e de família (alguns datando de meu pai e até de meu avô), pela formação comum e, principalmente, por certa maneira nossa de sentir e ver as coisas nacionais que resiste, no fundo, às divisões partidárias e até às incompatibilidades pessoais; e pelo provincianismo montanhês inextirpável, que acompanhava desde o primeiro Afonso Arinos nos seus anos de vida em Paris e que me segue sempre, a mim mesmo, fielmente, nos meus caminhos pelo mundo. [...] Mas, se a formação provinciana comum me fazia mais próximo dos colegas montanheses, a realidade crescente, dos partidos nacionais, deles em grande parte me separava. Os partidos centristas, burgueses, não exprimiam então nenhuma ideologia especí- 
23 Esse fator também é destacado nas análises das memórias de Arinos efetuadas por Arruda (1999) e por Lattman-Weltman (2005). fica, nenhum interesse econômico ou social conscientemente coordenado em programa. [...]. Os três partidos de centro representados em Minas exprimem interesses predominantemente municipais" (Arinos 1965, p. 72).

Mais do que cotejar e associar as produções escritas de Afonso Arinos e as de outros "memorialistas mineiros" trata-se aqui de enfatizar o contraste entre o empreendimento de Afonso Arinos e de outros políticos (atuantes em outras configurações estaduais) que produziram "memórias". Comparativamente a um conjunto de escritos autobiográficos de políticos do Rio Grande do Sul e do Maranhão analisado anteriormente (Grill 2012b), uma série de especificidades emerge, especialmente no que diz respeito à fase da vida em que ele se dedicou a escrevê-las, à percepção que apresentou sobre a política e ao significado que atribuiu ao registro pessoal do vivido. Tais singularidades decorrem, por seu turno, da autoridade intelectual herdada e conquistada, da inserção no universo cultural prévia à carreira política e do desenvolvimento de habilidades que permitiram investimentos de interpretação e racionalização pari passu às atividades políticas.

Sobre o primeiro item, é importante reter que os cinco volumes das memórias foram escritos e publicados entre 1959 e 1978, os três primeiros entre 1959 e 1968. Logo, os volumes 1, 2 e 3, que compõem o cerne do trabalho memorialístico, abrangendo da infância à saída temporária da cena política em 1967, foram redigidos em um período que abarca os oito anos (1959-1967) de exercício do primeiro mandato como Senador. Isto é, durante a carreira política e não após sair de cena, como é o mais recorrente entre políticos que se dedicam a esse gênero de escrita. Isso explica, em parte, a forma assumida pelo relato, como descrito abaixo.

O recurso utilizado amalgama registros de diário pessoal com o de autobiografia, transitando entre acontecimentos do passado e do presente, bem como transigindo no respeito à cronologia. Produzindo em pleno exercício de funções políticas, Arinos, invariavelmente, explicita a data em que está escrevendo. As narrativas são permeadas de relatos sobre situações e eventos dos quais vem participando no momento da escrita (em tom de diário), que se encontram entremeados à linearidade da autobiografia (em tom de memória) ${ }^{23}$. Abaixo, exemplos de trechos que ilustram o padrão de alternância entre apontamentos de momentos próximos e distantes no tempo, separados por poucas páginas:

"Rio, 15 de maio [1961] - Cheguei ontem de Brasília, onde passei uma semana rica de observações e experiências. Fiz dois discursos no Senado relatando as minhas recentes missões nas Nações Unidas e na conferência do Desarmamento. Os últimos acontecimentos no país e no partido tinham me desanimado bastante. Pensei a sério em deixar a política ou sair da UDN" (Arinos 1961, pp. 80-81).

"Rio, 17 de maio [1961] - Quando assumi meu mandato de deputado por Minas, em 1947, a U.D.N. era o segundo maior partido [...]" (idem, p. 82).

"Rio, 19 de abril [1964] - A vertigem dos dias. O turbilhão imprevisível. A convulsão político-militar que estourou no fim de março como um temporal nos trópicos [...]. Eu acompanhava a evolução de Magalhães Pinto desde a minha chegada da Europa. E acompanhava não só no sentido de informação, como também no da concordância. O Presidente Goulart, entregue a influências extremistas [...] enveredava para um beco sem saída" (Arinos 1965, p. 243).

"5 de junho [1964] - Voltando ao ano de 1953, observo, nos papéis de meu arquivo, que ele foi quase exclusivamente consumido, para mim, no exercício dos deveres de líder do partido e da oposição" (idem, p. 245).

Cabe destacar ainda que o livro A alma do tempo: formação e mocidade (primeiro volume, publicado em 1961, que abarca da infância à chegada à Câmara dos Deputados) foi redigido em pouco mais de um ano (outubro de 1959-dezembro de 1960). Nesse período, Afonso Arinos atuara como Senador 
(primeiro ano do seu primeiro mandato). Em 1961, ano em que ocupou por sete meses o ministério das relações exteriores no governo Jânio Quadros, abandonou a rotina de escrever suas "confissões".

Já A escalada (segundo volume, que contempla desde a atuação na Câmara dos Deputados, passando pelas eleições ao Senado e à Academia Brasileira de Letras, e chegando à posse no ministério das relações exteriores) foi confeccionada ao longo de quase quatro anos (dezembro de 1961-maio de 1965). A atuação como Senador e, principalmente, o momento conturbado da política nacional (crise que se estendeu da renúncia do presidente Jânio Quadros à deposição do seu sucessor, João Goulart) protagonizado por Afonso Arinos como líder partidário, parecem explicar os longos períodos sem escrever, perceptíveis nas datas registradas nos textos. Esse fator é, inclusive, constatado, destacado e contextualizado pelo próprio autor:

"5 de dezembro [1964] - Eu mesmo não consigo explicar a mudança de ritmo [comparação entre o tempo que levou para escrever o primeiro e o segundo volume], mas não quero perder tempo em procurá-la aqui. A única explicação que me ocorre, no momento, é que o primeiro volume foi escrito em grande parte, em ambiente nacional mais tranquilo [...]. Enquanto que, hoje, as incertezas do futuro são a cada passo marcadas pelas surpresas do presente. Há um tempo psicológico, diferente do tempo cronológico. As pausas criadoras vêm da alma, mais do que das horas. A atual tensão brasileira, a confusão e mediocridade da política nacional, dilacerada entre ambições e ódios sem grandeza, tiram a calma necessária ao labor literário daquele, como eu, a quem os deveres da função envolvem, por menos que o deseje, na sucessão de crises sem causa identificável nem saída previsível" (idem, p. 273).

Percebe-se assim, no trecho acima em que justifica as "pausas", uma das tantas demonstrações da oposição entre as exigências do pragmatismo da prática política (desqualificado) e da criação literária (celebrada). Arinos identifica nas conturbações e contingências conjunturais (e principalmente no ápice das crises) obstáculos à reflexão qualificada que julga necessária para os políticos de relevo, assim como valoriza a produção escrita (o "labor literário") como atividade enriquecedora da intervenção política acessível a poucos.

Por sua vez, O planalto (terceiro volume) foi escrito entre 1965 e 1968, abrangendo a atuação no Senado de 1961 até 1967. Nesse livro, o tom de diário se sobrepõe à narrativa autobiográfica. Entre outros fatores, contribui a proximidade temporal entre os acontecimentos narrados e o momento em que se efetuam os relatos. Tendência exacerbada nos dois últimos volumes, Alto-mar, Maralto e Diários de bolso seguido de retratos de noiva (publicados, respectivamente, em 1976 e 1979, quando Arinos ocupava assento no Conselho Federal de Cultura). O que foi constatado e grifado por Josué Montello na apresentação feita na orelha do livro Diário de bolso seguido de retrato de noiva.

Observa-se, mediante o cotejamento dos volumes, a crescente presença tanto de prefaciadores e apresentadores de destaque no cenário literário como de notas biográficas mais detalhadas sobre a vida política e literária de Afonso Arinos, que precedem os relatos do autor. Sobre o primeiro aspecto, cabe grifar algumas diferenciações. O primeiro volume conta apenas com uma nota biográfica da Editora José Olympio ${ }^{24}$, enquanto o segundo contém uma nota biográfica da mesma editora e a apresentação do próprio autor. O terceiro já traz a orelha do livro assinada por Francisco de Assis Barbosa e um trecho do discurso em homenagem a Afonso Arinos proferido por Guimarães Rosa. O quarto volume reproduz as "Louvações a Afonso Arinos" como elemento pré-textual, isto é, um conjunto de poemas dedicados ao autor por ocasião do seu aniversário de 70 anos, de autoria de Carlos Drummond de Andrade, Alphonsus de Guimarães Filho, Odilo Costa Filho e José Cândido de Carvalho. E o último volume, Diário bolso seguido de retrato de noiva, inclui um prefácio

${ }^{24}$ Destacando a importante relação de Afonso Arinos com a editora José Olympio, Gustavo Sorá (2010, p. 445) chega a localizá-lo como "parte do sistema de parentesco prático que rodeou a vida do editor e sua família nuclear", ou seja, membro da "casa" ou da "grande família" privilegiado pela proximidade e pelo afeto 
dispensado por José Olympio ("o patriarca").

${ }^{25}$ Como já foi salientado, Arinos voltará ao Senado através das eleições de 1986 que escolheu a Assembleia Constituinte. O lugar de "eminência" que assumiu na elaboração da constituição e no parlamento naquele período impede, no entanto, de interpretar esse "retorno" ao legislativo como uma volta ao espaço de lutas políticas e eleitorais.

${ }^{26}$ Lattman-Weltman (2005) sublinhou como o "desejo de transcendência" de Arinos se expressou também na sua retórica parlamentar, evocando modelos de estadistas, denunciando o caudilhismo (em um primeiro momento personificado por Vargas e, em um segundo momento, estendido para um sistema marcado pelo clientelismo, paralisia governativa e crise da institucionalidade política) e apostando no progresso social. de Carlos Drummond de Andrade e o texto de Josué Montello na orelha do livro, ambos escritos especificamente para a edição da obra.

As "memórias", que inicialmente mesclam o registro da narrativa autobiográfica com o do diário, fixando simultaneamente a autoimagem a ser transmitida e as versões pessoais sobre acontecimentos conjunturais, passam a servir, nos últimos volumes, como instrumento de consagração do personagem que aparentemente afastava-se do cenário político ${ }^{25}$. Logo, o uso político dos escritos acompanha o percurso da carreira política: "formação", "escalada", atuação no "planalto", saída de cena e "louvações".

No que tange às definições e classificações que Afonso Arinos faz sobre o funcionamento do mundo político, a comparação (já mencionada) com os outros políticos-memorialistas analisados parece relevante. Apesar de ser contemporâneo de parlamentares como Victorino Freire e Daniel Krieger, cujas memórias também foram alvo de exame anteriormente (Grill 2012b), enquanto eles exaltaram códigos políticos então vigentes como violência, lutas partidárias e relações pessoais na cúpula do poder, Arinos identifica os mesmos códigos reinantes no período 1945-1970, contudo assumindo posicionamentos críticos e distanciados em relação à atividade política ${ }^{26}$. Percepção que se estende às lutas políticas regionais, interpretadas sob a óptica da denúncia, do estranhamento e da superioridade de um universo do qual é oriundo (por relações familiares), faz parte e tem lugar de protagonismo.

Os trechos abaixo ilustram a afirmação feita acima:

"Na hora de sair para a função [comício], ao entrar no quarto para trocar de roupa, encontrei em cima da mesa um revólver 38 metido em belo coldre de couro de onça, debruado de baeta vermelha. Pensando em ser esquecimento do Chico Pinheiro, levei-lhe a arma de volta, ao que ele retrucou, pensativo: 'Não doutor, é para seu uso, esta noite; notei que o senhor não trazia arma...'. Era como se eu fosse para um comício sem paletó. Em Paracatu, andar desarmado é quase falta de educação. Para não ser indelicado, meti o bruto na cinta, mas passei-o, depois, ao Cornélio Palhares" (Arinos 1965, p. 124). “Apesar de tão mineiro, de tão provinciano pela minha herança paterna e
materna, a verdade é que eu passara praticamente toda a vida fora de Minas.
Havia, assim, uma contradição que eu sentia ao vivo, embora procurasse sempre
disfarça-la: a contradição entre o meu modo de ser mineiro, que me aproximava
dos colegas e correligionários, e o meu desgosto, o meu tédio por aquelas intrigas
sutis, aqueles ajustes de contas partidários, que eu sentia provirem de paixões
que me eram inteiramente estranhas, nascidas de choque entre pessoas que eu
não conhecia, ocorridos em municípios onde eu nunca havia pisado [...]" (idem,
p. 72).

"Em cima o grupo governativo: Presidente, ministros, deputados, Senadores e os aderentes do sistema majoritário, empreiteiros, negocistas, exploradores, indefinidos e de todas as castas, com suas mulheres apetitosas, perfumadas, queimadas de sol, cheias de jóias, cruzando de calças e sandálias as avenidas monumentais, ou as vielas afaveladas da cidade Livre. Abaixo deste vem o grupo dos altos burocratas, do Executivo e do Legislativo, do Banco do Brasil e das autarquias, mais ou menos na mesma situação. (...). Funcionários do Senado e da Câmara contam-me, citando nomes, episódios mesquinhos, cavações reles, que dão, em pequeno, idéia do que pode ser, em grande, o ambiente nos meios que dispõem do poder do dinheiro público" (Arinos 1961, p. 289).

Por fim, deve-se realçar o esforço de Afonso Arinos em rejeitar a imputação às suas "confissões" de "versões sobre a história". A despeito de dispor de trunfos diversos advindos da inserção em domínios culturais legítimos (títulos escolares, reconhecimento dos pares, acesso a editores, prefaciadores de relevo etc.), da posição política alcançada pelos membros do grupo familiar e por ele mesmo (cargos eletivos, atribuições no parlamento, postos em governos, dire- 
27 As referências recorrentes às redes de amigos literatos e políticos, assim como às viagens internacionais realizadas e às bibliotecas existentes nas distintas residências em que habitou, são indicadores do capital social e do capital cultural, herdados e acumulados. ção em partidos, entre outros) e do patrimônio familiar herdado e da posição social e política conquistada no plano regional e nacional ${ }^{27}$, seus relatos não assumem ou reivindicam o significado de uma contribuição à história política. Esses elementos que muitas vezes conferem autoridade ao escritor e às suas versões sobre eventos, personagens, movimentos etc. (Grill 2012b) neste caso servem para reivindicar: (i) a descrição literária do cotidiano da política; (ii) a caracterização distanciada do funcionamento da política, suas regras e códigos; (iii) o uso controlado/racionalizado do próprio gênero de escrita; (iv) a administração eficaz da autoimagem, da transmissão dos seus posicionamentos e da atribuição a posteriori da coerência dos seus movimentos.

\section{III.2. Arinos, a política e a configuração familiar}

${ }^{28}$ Afonso Arinos tinha quatro irmãos (Cesário, Caio, Virgílio e Afrânio) e uma irmã, Amélia, mais velhos do que ele. Além disso, tinha ainda uma irmã, Maria do Carmo e um irmão, João, mais novos.

${ }^{29}$ Doenças, internações e crises de depressão são descritas em detalhes em muitas passagens dos cinco volumes. Para uma análise desses aspectos na constituição de vocações literárias, ver Miceli (1977).
As características sociais do agente e do grupo familiar são fatores condicionantes da posição distanciada e distintiva em relação à política e aos políticos que imprime nos relatos e da relação ímpar com a escrita memorialística que estabelece. E esses dois aspectos, relação com a política e significado atribuído às memórias, se mostram interligados e lastreados nas disposições forjadas no espaço doméstico.

Inicialmente, cabe evidenciar o lugar ocupado entre os irmãos por Afonso Arinos. Quinto filho homem ${ }^{28}$ de um casal ligado a ramos de tradicionais famílias de políticos, como destacado no seu relato, não parecia "destinado" às atividades tidas como "masculinas", o que estaria interligado ao estigma de ser muito suscetível a ficar doente ${ }^{29}$. O trecho abaixo condensa esses dois aspectos persistentemente retomados por Arinos nos cinco volumes das suas memórias:

"Nasci, como já disse, quinto filho. [...] Cresci como que isolado, entre duas meninas. Isto explicará, talvez, até certo ponto, a diferença de minha formação. Nunca chegou o meu tempo de escalar o pico, de tomar banho no córrego do Leitão; de criar galo de briga; de procurar o veadinho fugido 'na ribanceira'; de montar no burro de seu Arquimedes ou no cavalo da ordenança; de criar, no quarto coelhinho branco de olhos vermelhos; de andar de bicicleta (nunca tive bicicleta própria, e esta foi uma das frustrações da minha meninice); de ir de súcia à Pampulha (fazenda de Bernardo Monteiro) ou à pedra do Sino (fazenda do meu avô), como os outros faziam. Minha mãe e minhas tias me metiam medo de doença; o horror aos ferimentos com sangue, por causa do tétano [...]. Creio que minha mãe, desanimada de dominar a malta dos 'outros', intentava submeter o quinto varão, nascido entre as meninas, de doce, contemplativo temperamento" (Arinos 1961, p. 15).

As referências à irmã (a mais velha, Amelinha) e à mãe, reproduzidas abaixo, indicam como Arinos projeta na sua imersão no universo feminino as razões das inseguranças e seguranças das suas ações, pulsões e aptidões.

“Tendo-a [a irmã, Amelinha] junto a mim [...] ela me era um auditório estimulante, e me dava uma grande confiança em mim, no terreno intelectual. Porém mais velha, (...) ela praticamente me levara pela mão, na vida [...]. A supremacia de Amelinha, no terreno do comportamento fêz-me como sou, ou penso ser: não tenho na minha ação [...] a mesma confiança que deposito na minha capacidade de estudo. Na ação, sem hesitar (eu muito raramente hesito) me omito, levado pelo tédio, timidez, preguiça, ou incapacidade. [...] Desabituei-me, assim, muito cedo, da competição e da disputa" (idem, p. 47).

"Como forma de espírito, sensibilidade, gostos e inclinações, pareço-me muito mais com minha mãe que com meu pai. Minha vida se parece com a dele. Suspeito que minha alma, com a dela" (Arinos 1965, p. 230).

Ao menos aparentemente, o lugar ocupado nas estratégias de sucessão política familiar o relegava a um papel auxiliar (como intelectual). No entanto, por um lado, a insistência do irmão Virgílio de Melo Franco para que Arinos fosse candidato, em 1945, e, por outro lado, a morte do próprio Virgílio, em 
${ }^{30}$ Outros irmãos mais velhos de Afonso Arinos também faleceram antes dele assumir o protagonismo na política nacional. Cesário Melo e Franco faleceu em $1918 \mathrm{e}$ Caio Melo e Franco em 1952.

31 A polaridade "contemplação" (Afonso Arinos) e "ação" (Virgílio) entre os irmãos também é destacada por Lattman-Weltman (2005, p. 22). Porém, a chave-explicativa adotada na sua análise reside na articulação, presente na "retórica" (uso da palavra) de Arinos, do intelectual e do político, da vocação (literatura) e da missão (posições de poder). Aqui estamos chamando a atenção para a divisão do trabalho de dominação política na configuração familiar e as tensões ou complementaridades que podem gerar.
1948 (quando Arinos exercia seu primeiro mandato como deputado federal), foram elementos que contribuíram para projetá-lo ao primeiro plano no cenário político nacional ${ }^{30}$. A partir disso, os atributos do "homem de ideias" (próprio à intelectualidade) fizeram emergir com mais força ainda o tribuno, legislador e líder político.

Na passagem abaixo, Arinos descreve os argumentos manifestos que, para Virgílio, justificariam a sua irrevogável entrada na política (quase como um dever genealógico), bem como indica motivos implícitos relacionados ao desprovimento do irmão em relação a determinados trunfos disponíveis para ele. Assim, fixam certas compensações que equiparam irmãos com virtudes distintas.

"No entanto, sem qualquer consulta, ele revelou-me, e alguns amigos, o propósito de conservar-se fora da Assembleia. Foram inúteis os meus argumentos. Virgílio manteve-se inabalável. 'Todos nós temos de passar pelo parlamento disse-me ele - e você não pode escapar a esta tradição da nossa gente'. [...] As razões que levaram Virgílio a ter tal procedimento eram várias e concorrentes. Havia o desprendimento, o empenho de me empurrar, a confiança em mim. Havia também uma certa desconfiança nas suas próprias possibilidades, em face das exigências da função, pois ele sabia que não era jurista, nem orador" (Arinos 1961, p. 418).

Por conseguinte, a comparação com o irmão que é considerado como um "vocacionado" para a política e para outras atividades tidas como masculinas, reforça, ao longo dos volumes, elementos da personalidade de Afonso Arinos. Virgílio representaria o protótipo do "homem de ação" enquanto Arinos encarnaria o "homem de pensamento". Em passagem, Arinos associa o irmão a imagens como: "tigre em uma jaula", portador de "uma força elástica que o animal abriga e esconde, e que o faz partir, num relâmpago, da quieta postura ao salto certeiro". Manifesta ainda seu espanto a respeito da "capacidade de resistência, de ação direta e de participação total" demonstrada pelo irmão. Concluindo, declara: "Posso dizer que, no fim da sua vida, quando nossa identidade era maior, eu pensava por ele e ele agia por mim" (idem, pp. 291-292) $)^{31}$.

Ao caracterizar o irmão e a "tradição familiar", Arinos externaliza de forma exemplar sua relação ambígua com a política já demonstrada anteriormente. Quer dizer, revela ao mesmo tempo proximidade e complementaridade entre as competências dos "homens de ação" e dos "homens de pensamento". Quando os relatos são embebidos em vínculos afetivos e se expressam por construções que comportam admirações, rejeições, interdições e prescrições de papeis, emerge com força o duplo vínculo que a família possui com o universo das lutas políticas e com o âmbito intelectual (sintetizada na reivindicada complementaridade entre os irmãos), mas principalmente o quão imerso nessas duas gramáticas encontrava-se o próprio Arinos e quão conflitivo pode ser o pertencimento aos dois mundos. Observa-se a sutil mudança de ênfase na qualificação do universo político que pode assumir traços mais críticos, céticos e distanciados quando se refere aos "pares" e práticas dominantes.

A configuração familiar teria incitado ao mesmo tempo uma concepção de "vocação política" espelhada no pai e no irmão e a reivindicação da "vocação literária" como "refúgio" das injunções que pesavam sobre eles em virtude da divisão dos papeis no grupo familiar.

Desse modo, compreende-se o porquê de, em vários momentos, a crítica desferida à atividade política venha acompanhada de exaltação da sua propensão à literatura. Ao que tudo indica, o uso da condição de intelectual funciona, por um lado, como justificação para determinados desajustes entre a sua maneira de atuar politicamente e as regras do jogo da política valorizadas pela 
${ }^{32}$ Fato também observado por Le Bart (1998) e Grill e Reis (2012) em outros estudos sobre políticos escritores. maior parte dos jogadores. Por outro lado, serve de instrumento de legitimação de um modo próprio de exercer o métier e das escolhas que efetuou acerca das modalidades de atuação, dado a submissão à predestinação familiar pela carreira política.

"Repassando tudo, não me arrependo, nem me envergonho, do que me foi dado a fazer, mas creia o leitor, não adquiri nenhum entusiasmo pela vida política, nem pela notoriedade que ela traz. Sinto-me mais velho, talvez fisicamente desgastado pelos choques e emoções do decênio, mas na minha inteligência e no meu coração subsistem, dominantes e jovens, o gosto do estudo e o amor das letras" (Arinos 1961, p. 122).

"Em mim, porém, a paixão política não é predominante e, por isso mesmo, não consigo dissociar minha ação, nesse terreno, da ordem do raciocínio e da convicção" (Arinos 1965, p. 137).

Não por acaso, a atividade literária parece conferir a Afonso Arinos, acima de tudo, um lugar distanciado e distintivo em relação a outros políticos. Não é de se estranhar, portanto, as passagens recorrentes em que é valorizada a prática da escrita, da reflexão, do raciocínio etc. como meio de sair da rotina política ${ }^{32}$, bem como de localização de uma posição de superioridade ou, ao menos, da detenção de atributos excedentes, compensatórios e distintivos, tais como: "Sinto necessidade de refugiar-me na leitura ou na escrita, para manter o meu equilíbrio íntimo, conservar o que suponho ser o lado mais autêntico do meu espírito" (Arinos 1961, p. 320) ou "Eu me encontro agora nas condições propícias para instruir-me melhor sobre as questões que se colocam acima do cotidiano" (Arinos 1968, p. 122).

"Por tudo isso, contrariando a velha tradição da família, não me metia em política, nem por ela me interessava. [...] Talvez essa dificuldade de definição é que me tenha levado a procurar refúgio privativo nas letras, com abandono de qualquer preocupação com a política, que, no entanto, me cercava, pois absorvia os meus" (Arinos 1961, p. 88).

Na mesma linha, então, é possível entender o porquê da justificativa para a redação das memórias estar baseada no gosto e na necessidade de escrever, de fazer literatura, diferentemente das justificativas dadas por outros políticos para a confecção de textos deste tipo como solicitação de familiares, outros políticos, correligionários, assessores, amigos etc. para que fornecessem seus testemunhos e versões sobre a história (Grill 2012b). Nas primeiras páginas do primeiro volume, já afirma: "Pretendo fazer dele [livro], antes de tudo, como já disse, uma obra de literatura" (Arinos 1961, p. 5). Por meio da escrita literária ele parece querer exatamente expurgar as injunções derivadas das outras inserções, recusando, ao menos parcialmente, inclusive, afirmar-se por outras aptidões possuídas e por distintos conhecimentos e saberes advindos do Direito, da Sociologia ou da Política, por exemplo:

"Se me acontecer pensar juridicamente as matérias do meu curso de Direito Constitucional, encarar do ponto de vista da sociologia política os episódios partidários ou outros que tenha de viver como homem público, a verdade é que tudo que sinto de mais espontâneo e natural no meu espírito tende a considerar intelectualmente e mesmo literariamente a vida. [...] O direito e a política podem conformar-me segundo um modelo utilitário. Mas, deixado a mim mesmo, reintegro-me no meu mundo natural, que é o da Literatura" (Arinos 1961, p. 5).

Apoiado nessa autoimagem, associada, por sua vez, à afirmação precoce em "rodas" e "casas" literárias, Afonso Arinos define, de forma original, o tipo de relato produzido. Ao distanciamento propiciado pela literatura, soma-se a ativação de uma técnica de ficção para salvaguardar-se de uma leitura que venha projetar na obra a busca tanto da autobiografia quanto da versão histórica. Essas são rejeitadas por associação. Quer dizer, Afonso Arinos liga autobiografia e memória histórica para distanciar-se de ambos os gêneros de escrita. 
Para ele: "o trabalho do memorialista se torna mais literário na medida em que ele se omite, e mais histórico na medida em que ele se apresenta". $\mathrm{Na}$ mesma linha, assevera que quanto mais consegue neutralizar-se e deixa aparecer "uma trama de fatos, de ambientes e de seres, colhidos ao mundo exterior, e intimamente ligados à vida do autor", mais próxima do gênero das memórias literárias se encontra. Prosseguindo, afirma que "omitindo-se, ele utiliza uma técnica aproximada da do ficcionista, embora nunca, é bom acentuar, se desligando dos compromissos com a verdade fatual, e pode realçar os valores literários das descrições e interpretações" (idem, p. 6).

Defende, com efeito, que seu projeto é de fazer um autorretrato e não uma autobiografia. Uma vez que:

“Auto-retrato é diferente de autobiografia, na medida em que as memórias literárias são diferentes das memórias históricas. O escritor não pretende construir uma personalidade, mas revelar uma pessoa. E esta revelação se processa não mediante o desnudamento direto de uma alma, mas pelo funcionamento de um espírito, de uma inteligência, que assistimos descrevendo, interpretando, ou julgando paisagens, situações, seres e ideias que impressionaram o decurso, ora tranquilo, ora tumultuoso de uma vida" (Arinos 1961, pp. 6-7).

Novamente, o esforço reside em demonstrar sua capacidade de descrição distanciada e de racionalização. Postula, no uso da linguagem literária e na capacidade de mobilizá-la, uma produção que não se pretende assentar sobre o abstrato da subjetividade, "da alma", mas de uma apropriação mais ampla e reflexiva, como expressão do "espírito" e da "inteligência", capaz de descrever, interpretar e julgar. Nesse sentido, a literatura expressa a capacidade de exercício da razão e a possibilidade de refúgio não só da política, mas do Direito, da diplomacia etc. A memória literária, por sua vez, objetivaria ou sintetizaria sua habilidade de enxergar "situações" em um outro plano e a perícia para examinar o "cotidiano" inescapável, isto é, as funções políticas, jurídicas, diplomáticas e docentes que dele se apossaram.

Para finalizar esta seção, é preciso reforçar que a relação ambígua com a política evidenciada aqui não implica uma auto-apresentação de Arinos, como político, marcada pela percepção de impotência ou incompetência em lidar com esse domínio da vida social. A herança política familiar e os trunfos conquistados são referidos sistematicamente como atributos que o credenciavam ao lugar de protagonismo nos embates políticos, ainda que nem sempre assumidamente desejados.

Ao longo de todos os volumes das memórias, associações com os ascendentes políticos, diplomatas, escritores etc. são reivindicadas. Para tanto, relatos de personalidades que conviveram com "os Melo Franco" testemunham "semelhanças" entre ascendentes e descendentes.

"E o caro Prudente dedicou-lhe [primeiro voto proferiu na Constituição de Justiça] uma crônica que me comoveu sinceramente. [...] De resto, ele próprio escreveu sob funda emoção, de vez que recordava o tempo em que meu pai presidia e o seu pai [Antonio Carlos, ex-governador de Minas Gerais] era membro destacado daquela mesma Comissão de Justiça. Apesar dos elogios, não posso deixar de transcrever aqui alguns períodos da crônica de Prudente, cujo título era 'Herdeiro e Sucessor'” (Arinos 1965, p. 86).

"O cronista parlamentar do jornal do Comércio [...] publicou o seguinte, na edição de 7 de dezembro, sobre o meu discurso [de 17 de novembro de 1947 sobre Afonso Pena]: 'Referimo-nos à oração do Sr. Afonso Arinos que [...] revelou possuir todas as credenciais para ser, em 1947, o continuador das nobres e famosas tradições do pugilo de deputados mineiros de 1906 - Carlos Peixoto, Pandiá Calógeras, Davia Campista, Gastão da Cunha, Afrânio de Melo Franco, João Luís Alves e Estevão Lobo"” (idem, p. 99; sem grifos no original). 
Do mesmo modo, a familiaridade com cenários (lugares, universidades, casas legislativas e embaixadas) que emolduram as narrativas sobre as vivências, ajudam-no a realçar uma espécie de "extirpe" e a inscrever as gerações de "homens públicos" em lugares de poder e de memória.

“A minha entrada na Câmara dos Deputados deu-se nas sessões preparatórias [...]. O recinto do palácio Tiradentes estava em reparos, o que levou o presidente a convocar aquelas sessões para o salão nobre. [...] Eu já o conhecia [...]. Ali haviam falado meu pai e Virgílio. Eu não entrava novato, naquela casa, que me era, a bem dizer, familiar. Meu irmão, meu pai, meus dois avós tinham passado por ela. E outros, mais afastados pelo tempo. Eu era o oitavo do meu sangue que, entre o Império e a República, vinha representar o povo mineiro na casa do povo brasileiro" (Arinos 1961, p. 427).

"[Sobre participação na Conferência em Genebra] [...] viemos encontrar a douta Genebra. [...] Na minha mocidade, esta terra de Calvino, Rousseau e Amiel era apenas o palco reduzido de uma luta de prestígio limitadamente europeia, cena do jogo sutil de oratória polida, entre Inglaterra e França, com a assistência de outros cavalheiro bem-educados, como meu pai, de colarinho duro, monóculo e bengala. [...] O prestígio do meu pai vinha da sua reputação de jurista [...]. Hoje as conferências sucessivas que aqui se reúnem todo o ano [...] tratam de coisas inimagináveis no meu tempo de rapaz" (Arinos 1968, p. 128).

Da mesma forma, "capacidade de estudo" (Arinos 1961, p. 47); "senso de autoridade" (idem, p. 53); "veemência oratória" (idem, p. 164), empenho em "extrair de casos concretos as teses jurídicas que eles comportavam [...] a estabelecer princípios, interpretar disposições e propor normas que sempre transcendiam e davam uma certa estabilidade às soluções" (Arinos 1965, p. 93), "força persuasiva" (idem, p. 131) e "recursos de exposição verbal" (idem, p. 155) são apenas algumas das qualidades auto-atribuídas ao longo dos volumes. Afonso Arinos recorre, com alguma insistência, à importância dessas competências para o exercício de atribuições legislativas (plenário, comissões, liderança etc.), administrativas (realizações como ministro e secretário de estado) e públicas em geral (promotoria, Conselho Federal de Cultura etc.).

\section{Conclusões: ativação e gestão de múltiplas identidades}

As narrativas biográficas e os "autorretratos" que fixam as identidades estratégicas (Collovald 1988) de Afonso Arinos revelam os processos de mutinotabilizações prevalecentes ao longo do século XX no Brasil e que decorrem da multiposicionalidade (Boltanski 1973) de uma elite letrada e votada que comandou, simultaneamente, distintas esferas de atuação política e cultural. Desvelam, ainda, como o uso da escrita e o reconhecimento como escritor foram trunfos contundentes para encarnar o papel de porta-voz da "nação", que indissociavelmente prescrevia a habilidade intelectual do "intérprete da nação" e a capacidade política do "tribuno da identidade".

O exercício da função da representação política, como em outros cenários, implica o domínio de duas atividades complementares: por um lado, movimentar-se de forma eficaz em um sistema de instituições, de regras, de posições, de negociações, de alianças, de coalizões e de enfrentamentos na esfera que compõe o aparato formal e informal da política, por outro lado, forjar e/ou mobilizar com maestria identidades coletivas, produzindo símbolos de reconhecimento para coletividades (Pizzorno 1986). A partir do exame do caso de Afonso Arinos, percebe-se com bastante nitidez o que outros estudos já demonstraram (Pécaut 1990; Coradini 2003; Grill \& Reis 2012; Reis \& Grill 2013; Reis 2007, entre outros): no Brasil, tais atribuições exigem um duplo e indissociável reconhecimento, como homens de ideias e de ação políticas, com pesos e intensidades distintas, racionalizações e justificações variadas. 
Desse modo, representar politicamente é incumbência de agentes que manejam, ao mesmo tempo, saberes específicos do mundo da política institucional e conhecimentos relativos à identidade, à matriz comum, às formas de sociabilidade e comunicação, às concepções sobre o social e o político, enfim, à cultura política dos intelectuais.

O contexto em tela e o caso em análise permitem ainda uma rápida comparação com outras configurações nacionais (centrais e periféricas) no que tange à relação dos intelectuais com a política. Em uma direção, pode-se tomar o trabalho de Sapiro (2012) sobre as modalidades de intervenção política dos intelectuais na França. A autora mostra como os processos de acúmulo de capital simbólico, de autonomização e de especialização interagem reciprocamente, condicionando as formas de engajamento e o valor dos bens culturais mobilizados nas "causas". Em outra direção, parece relevante considerar a investigação de Sigal (2012) sobre o cenário argentino, em que destaca, ao mesmo tempo, a débil influência dos intelectuais sobre o Estado e os partidos, a prevalência de atividades culturais ligadas à produção de noções comuns concernentes à ordem social e a dupla dependência de instâncias exteriores: o domínio político e de centros culturais metropolitanos. O perfil de Arinos, a dinâmica multidimensional descrita e o cotejamento com esses cenários explicitam as peculiaridades do quadro em análise, quer dizer, a heteronomia como fonte de trunfos mobilizáveis em distintos domínios (contrastante com o caso francês) e a vinculação umbilical com o Estado (diferente do caso argentino) e com a política, suas linguagens, problemáticas construídas, funções exigidas, competências requeridas etc.

Por fim, o exame do corpus discursivo formado por relatos biográficos e memorialísticos possibilitou igualmente compreender como o volume dos capitais possuídos e a combinação entre eles, assim como a associação com origens familiares e títulos escolares, conferem a Afonso Arinos, além de autoridade para a imposição de definições sobre as formas legítimas de exercício do métier do político e do "homem de letras", um potencial sem equivalentes de gestão das identidades estratégicas e de difusão ou ressonância da autoimagem em outros discursos e relatos provenientes de personalidades ou instituições que desfrutam igualmente de prestígio político e intelectual.

O curioso, porém, é que seja possível perceber, quando se examina sua produção autobiográfica, profundos conflitos, ambivalências, dilemas e deslocamentos de sentidos decorrentes das responsabilidades herdadas, da divisão do trabalho político familiar, da inscrição em domínios diversos, da compatibilidade de gramáticas divergentes etc. Ou seja, a despeito dessa convergência entre a construção do agente apresentada nas memórias e a reprodução observada nas biografias sobre ele escritas, as obras revelam um mosaico de prescrições e repertórios que delineiam uma identidade clivada de várias faces, não necessariamente conciliáveis ou livres de processos traumáticos originários da justaposição ou redefinição de papeis ocasionados pela reconfiguração do espaço político e pela readequação das estratégias de reprodução da família.

Igor Gastal Grill (igorgrill@terra.com.br) é Doutor em Ciência Política pela Universidade Federal do Rio Grande do Sul (UFRGS) e Professor do Programa de Pós-Graduação em Ciências Sociais da Universidade Federal do Maranhão (UFMA).

\section{Referências}

Abreu, A., ed. 2001. Dicionário Histórico-Biográfico Brasileiro pós-30. Rio de Janeiro: FGV/CPDOC.

Almeida, A.W. 2008. A ideologia da decadência: leitura antropológica a uma história da decadência da agricultura do Maranhão. Rio de Janeiro: Editora Casa 8.

Arinos, A. 1955. Um estadista da República. Rio de Janeiro: José Olympio Editora. 1961. Alma do tempo. Memórias. Rio de Janeiro: José Olympio Editora. 
1965. A escalada. Memórias. Rio de Janeiro: José Olympio Editora.

1968. Planalto. Memórias. Rio de Janeiro: Livraria José Olympio Editora.

Arinos Filho, A. 2009. Afonso Arinos de Mello Franco: cadeira 25, ocupante 5. Rio de Janeiro: ABL.

Arruda, M.A.N. 1999. Mitologia da mineiridade. São Paulo: Brasiliense.

Bonavides, P., ed. 1976. As tendências atuais do direito público: estudos em homenagem ao professor Afonso Arinos. Rio de Janeiro: Forense.

Boltanski, L. 1973. L'espace positionnel: multiplicité des positions institutionnelles et habitus de classe. Revue Française de Sociologie, 14(1), pp. 3-26.

Bourdieu, P. 1989. Espaço social e gênese das classes. In: ___ O poder simbólico. Lisboa: Difel. 1996a. A economia das trocas lingüísticas: o que falar quer dizer. São Paulo: Edusp. 1996b. A ilusão biográfica. In: ___ Razões práticas. Campinas: Papirus.

Canêdo, L.B. 1997. Metáforas da família na transmissão do poder político. Cadernos do CEDES, 42, pp. 29-52.

Collovald, A. 1988. Identité(s) Stratégique(s). Actes de la Recherche en sciences Sociales, 73, pp. 29-40. 1999. Jacques Chirac et le gaullisme. Biographie d'un Héretier à Histoires. Paris: Belin.

Coradini, O.L. 1998. Panteões, iconoclastas e as Ciências Sociais. In: L.O. Felix; C.P. Elmir, eds. Mitos \& Heróis: construção de imaginários. Porto Alegre: Editora da Ufrgs.

.2003. As missões da "cultura" e da "política": confrontos e reconversões de elites culturais e políticas no Rio Grande do Sul (1920-1960). Estudos Históricos, 32, pp. 125-144.

Coradini, O.L.; Reis, E.T. 2012. Transações culturais, intelectuais e as ciências sociais. Revista Pós Ciências Sociais, 9(12), pp. 9-17.

Dézalay, Y.; Garth, B. 1998. A dolarização do conhecimento técnico-profissional do Estado: processos transnacionais e questões de legitimação na transformação do Estado (1960-2000). Revista Brasileira de Ciências Sociais, 15(43), pp. $163-175$.

Garcia Jr., A. 1993. Les Intellectuels et la Conscience Nationale au Brésil. Actes de la Recherche en Sciences Sociales, 98, pp. 20-33.

Grill, I.G. 2008. Processos, condicionantes e bases sociais da especialização política no Rio Grande do Sul e no Maranhão. Revista Sociologia e Política, 16(30), pp. 65-87. . 2012a. Ismos, ícones e intérpretes: as lógicas das etiquetagens na política de dois estados brasileiros (MA e RS). Revista de Sociologia e Política, 20(43), pp. 111-138.

. 2012b. Memórias de políticos brasileiros: produção escrita, gestão de imagens e teorizações nativas do jogo político. Política \& Sociedade, 11(21), pp. 11-40.

Grill, I.G.; Reis, E.T. 2012. O que escrever quer dizer na política? Carreiras políticas e gêneros de produção escrita. Revista Pós Ciências Sociais, 9(17), pp. 101-121.

Guilhot, N. 2001. Les professionnels de la démocratie. Logiques militantes et logiques savantes dans le nouvel internationalisme américain. Actes de la Recherche em Sciences Sociales, 139, pp. 53-65.

Lattman-Weltman, F. 2005. A política domesticada: Afonso Arinos e o colapso da democracia em 1964. Rio de Janeiro: FGV.

Le Bart, C. 1998. L'écriture comme modalité d'éxercice du métier politique. Revue Française de Science Politique, 48, pp. 76-96.

Maia, T.A. 2012. Os Cardeais da cultura nacional: o conselho federal de cultura na ditadura civil-militar. São Paulo: Itaú Cultural/Iluminura.

Miceli, S. 1977. Poder, sexo e letras na República Velha. São Paulo: Editora Perspectiva. 1979. Intelectuais e classe dirigente no Brasil (1920-1945). Rio de janeiro: Difel.

Nava, P. 1983. O intelectual e o político: encontros com Afonso Arinos. Brasília: Senado Federal.

Neveu, E. 2003. Métier politique: d'une institutionnalisation à une autre. In: J. Lagroye, ed. La Politisation. Paris: Belin.

Pécaut, D. 1990. Os intelectuais e a política no Brasil: entre o povo e a nação. São Paulo: Ática.

Pizzorno, A. 1986. Sur la Rationalité du Choix Démocratique. In: P. Birnbaun; J. Leca, eds. Sur l'individualisme. Paris. Presses FNSP.

Pontes, H. 1988. Retratos do Brasil: um estudo dos editores, das editoras e das “coleções brasilianas”, nas décadas de 1930, 40 e 50. Boletim Informativo e Bibliográfico, 26, pp. 56-89.

Quintella, M.M.D. 1984. Cultura e poder ou espelho, espelho meu: existe alguém mais culto do que eu? In: S. Miceli, ed. Estado e cultura no Brasil. São Paulo: Difel.

Reis, E.T. 2013. Saberes em movimento: transações entre intelectuais, definições de ciências sociais e a política. In: E. Seidl; I.G. Grill, eds. As Ciências Sociais e os espaços da política no Brasil. Rio de Janeiro: Editora da FGV.

Reis, E.T.; Grill, I.G. 2008. Letrados e votados: lógicas cruzadas do engajamento político no Brasil. Tomo, 13, pp. $127-168$. 2013. Produção intelectual e carreiras políticas no Brasil. In XVI Congresso Brasileiro de Sociologia. Salvador

2015. Trajetórias de multinotabilidades no parlamento brasileiro: dinâmicas políticas, produção escrita e reputações pessoais. Dados. N. ${ }^{\circ} 58$, v.2.

Sapiro, G. 2012. Modelos de intervenção política dos intelectuais: o caso francês. Revista Pós Ciências Sociais, 9(17), pp. $19-50$.

Sigal, S. 2012. Intelectuais, Cultura e Política na Argentina. Revista Pós Ciências Sociais, 9(17), pp. 51-66.

Silva, S. 2008. As "rodas" literárias no Brasil nas décadas de 1920-30. Troca e obrigações no mundo do livro. Latitude, 2(2), pp. 182-210. 
Sorá, G. 2010. Brasilianas. José Olympio e gênese do mercado editorial brasileiro. São Paulo: Edusp. Venancio Filho, F. 1981. Política e Direito. Brasília: Editora da UnB.

Weber, M. 1987. Economia y Sociedad. México: Fondo de Cultura Económica.

\title{
Outras fontes
}

Politix. 2004. Dossier : Trajectoires de la notabilité. Politix, 17(67).

\begin{abstract}
In this article are analyzed the social bases and institutional supports that constitute Afonso Arinos' multiple notabilities, protagonist of political and intellectual disputes throughout the twentieth century in Brazil. The focus in one hand is on the amalgam between social notoriety (genealogic, family, professional, intellectual) and political reputation (assignments, jobs, leaderships, attributes and deeds), on the other hand, the tensions arising from inherited responsibilities, the division of family's political work, the enrollment in various fields, the compatibility of different grammars, among others. From the biographical and autobiographical production on the character are explored: 1) the connections between the "vocation" to represent (in the various meanings of the expression) and the "art" of writing, 2) the social, ideological and political uses of the collective credit production work over a political personality; 3) the management of his own image and native theorizing about political profession present in the memories of a politician. The treatment of these dimensions reveals the outlines of a mosaic of legitimate competencies for political and intellectual consecration. Skills, knowledge and assets not necessarily reconcilable or free of traumatic processes originating from its juxtaposition or role redefinition, caused on its turn by the reconfiguration of political space and demands for readjustment of the family reproduction strategies. Similarly, by analyzing a set of position takings by and about the character, distinct multiple notability building mechanisms come to surface, from the agent and certain insertion domains that appears as product and producers of the multiple positioning enjoyed by a literate and voted elite that commanded different spheres of politics and culture simultaneously. Besides that, the possibility to understand how the amount of owned capitals and the combination between them granted to Afonso Arinos not only the authority to produce, manipulate and impose definitions on the exercise of the politician's and "man of letters"” métier, as well as the unique accumulated potential for the management of strategic identities.
\end{abstract}

KEYWORDS: political elite; intellectuals; memoirs; biographies; political profession.

License information: This is an open-access article distributed under the terms of the Creative Commons Attribution License, which permits unrestricted use, distribution, and reproduction in any medium, provided the original work is properly cited. 